\title{
IMPAK ELEKTRIK DALAM PERKEMBANGAN INDUSTRI BIJIH TIMAH DI SELANGOR DAN PERAK, 1927 - 1940
}

\author{
Mohamad Khairul Anuar Mohd Rosli \\ Ahmad Kamal Ariffin Mohd Rus
}

\begin{abstract}
Abstrak
Kajian ini menganalisis kepentingan bekalan elektrik kepada perusahaan bijih timah di Perak dan Selangor. Kemunculan elektrik sebagai tenaga baharu pada penghujung abad ke-19 dilihat bertepatan dengan keperluan tenaga kerja dalam kalangan pengusaha lombong. Kepesatan kegiatan melombong bijih timah khususnya yang berpusat di Lembah Kinta dan Kuala Lumpur menyebabkan penggunaan kepada tenaga buruh semata-mata tidak dapat menjamin kelancaran operasi syarikat perlombongan. Lantaran itu wujud keperluan untuk mempelbagaikan tenaga kerja menerusi penyediaan tenaga alternatif seperti elektrik. Bagi memenuhi tuntutan tersebut, pihak kerajaan berusaha membangunkan kemudahan bekalan elektrik sebagai obligasinya untuk memacu pertumbuhan sektor perlombongan. Selain itu, syarikat swasta juga turut memainkan peranan dengan menyediakan perkhidmatan bekalan elektrik sekali gus memudahkan pengusaha lombong mendapatkan bekalan elektrik. Didapati menjelang tahun 1920-an, tenaga elektrik telah digunakan secara meluas dan menjadi tenaga kerja yang penting dalam perusahaan bijih timah. Ternyata kemudahan bekalan elektrik yang disediakan telah membantu pengusaha lombong meningkatkan kecekapan pengurusan operasi dari segi tenaga kerja dan kaedah melombong. Penyediaan bekalan elektrik telah memenuhi keperluan tenaga kerja yang cekap dalam kalangan pengusaha lombong bagi mengatasi masalah kekurangan tenaga buruh. Pada masa yang sama, penggunaan tenaga elektrik juga telah membuka ruang kepada pemodenan kaedah melombong seterusnya menjadikan kerja-kerja mencari gali bijih timah lebih berkesan. Ringkasnya, kemudahan bekalan elektrik yang disediakan kepada pengusaha lombong di Lembah Kinta dan Kuala Lumpur telah berjaya memastikan kelangsungan perusahaan bijih timah dan membawanya ke arah yang lebih moden.
\end{abstract}

\section{Abstract}

This study analysed the importance of electricity supply to the tin industry in Perak and Selangor. Due to the heightened tin mining activities especially in Kinta Valley and Kuala Lumpur, the advent of electricity as a new energy source toward the end of 19 century fulfilled the required workforce for a number of mining operators. To rely soley on manpower would not make the mining company operated efficiently. Therefore, electricity would be the alternative to support the workforce. To fulfill this need and to accelerate the growth of mining sector, the government made efforts to carry out their obligations by building the electricity supply facilities. Besides, the private companies too played the roles to provide electricity supply services. At the same time, the privae companies facilitated the mining operators to get their electricity supply. It was found that by 1920s, electricity was widely used and became vital to workforce support in the tin mining industry. Thus, this development proved that the electricity supply and its facilities helped the mining operators to significantly 
advance their workforce support management and mining methods. In other words, firstly, the electricity supply solved the labour shortage since its workforce support management worked efficiently for a number of mining operators. Secondly, the electricity supply modernised the mining methods which made the mining activities operated more effectively. In short, the electricity supply facilities which provided by the government and private companies to the mining operators in Kinta Valley and Kuala Lumpur successfully prolonged the mining industry survival and made the mining industry great strides to be more modern.

\section{Pengenalan}

Kekayaan bijih timah telah menjadi daya penarik kepada kehadiran pemodal asing ke negeri-negeri Melayu terutamanya Perak dan Selangor. Kepentingannya sebagai komoditi eksport yang menguntungkan telah mempengaruhi pemodal asing untuk turut sama mengusahakan lombong bijih timah. Misalnya, pemodal Cina dari Melaka dan Singapura yang pada peringkat awal berperanan menyediakan modal kepada pengusaha tempatan khususnya golongan elit Melayu dilihat mula terlibat secara langsung dalam perusahaan bijih timah dengan menjadi pengusaha lombong. Lantaran itu wujud keperluan untuk pihak British menjaga kepentingan para pemodal sehingga membawa kepada campurtangan di negeri-negeri Melayu menjelang tahun 1870-an bermula dengan Perak diikuti Selangor, Negeri Sembilan dan Pahang. Keempatempat negeri tersebut kemudiannya digabungkan di bawah sebuah unit pentadbiran yang dikenali sebagai Negeri-negeri Melayu Bersekutu (NNMB) pada tahun 1896. Pengukuhan pentadbiran British menerusi NNMB memberi kelebihan kepada pemodal untuk terus terlibat dalam perusahaan bijih timah.

Bagi pihak British sendiri, sektor perlombongan sememangnya dititikberatkan kerana menyumbang sebahagian besar kepada hasil pendapatan. Menurut John G. Butcher, antara tahun 1890 sehingga 1894, sebanyak 38.8 peratus hasil pendapatan British di keempat-empat negeri berkenaan diperolehi menerusi kutipan cukai perlombongan diikuti cukai pajakan candu sebanyak 33peratus. ${ }^{1}$ Pada tahun 1898 , sebanyak \$9.4 juta disumbangkan menerusi kutipan cukai perlombongan sebelum meningkat kepada \$28.8 juta menjelang tahun $1907 .{ }^{2}$ Bertepatan dengan dasar pihak British yang mengutamakan sektor perlombongan, pelbagai inisiatif telah diperkenalkan untuk mewujudkan persekitaran yang kondusif kepada pemodal. Hal ini sebagaimana yang dinyatakan oleh Frank Swettenham bahawa, "The Government cannot do the mining and the agriculture, but it can make it profitable for other to embark in such speculations by giving them every reasonable facility and that we have tried to do". ${ }^{3}$ Pelbagai bentuk kemudahan asas telah disediakan sehingga menarik kehadiran pemodal Eropah dan Cina seterusnya membawa kepada pembukaan lebih banyak lombong bijih timah.

Pembukaan lombong bijih timah menuntut penyediaan tenaga kerja yang mencukupi bagi memastikan kelancaran operasi syarikat perlombongan. Justeru pihak kerajaan memberi galakan kepada kemasukan tenaga buruh khususnya buruh Cina untuk memenuhi permintaan dalam kalangan pengusaha lombong yang semakin meningkat. Contohnya kepesatan aktiviti melombong bijih timah di Lembah Kinta menjelang tahun 1880-an membuatkan semakin ramai tenaga buruh dibawa masuk. Didapati bilangan buruh Cina yang bekerja di Lembah Kinta pada ketika itu mencatatkan peningkatan kepada 5,000 orang berbanding 2,000 orang pada tahun 1874. ${ }^{4}$ Pada tahun 1910, seramai 91,165 buruh terlibat dalam perusahaan bijih timah 
di Perak dan daripada jumlah tersebut seramai 61,530 buruh tertumpu di Lembah Kinta. ${ }^{5}$ Sementara itu di Selangor, bilangan buruh mencatatkan peningkatan daripada 49,202 orang pada tahun 1897 kepada 61,530 orang pada tahun $1900 .{ }^{6}$ Di sebalik statistik tersebut menunjukkan perusahaan bijih timah di Perak dan Selangor sehingga dekad terawal abad ke-20 masih lagi berintensifkan tenaga buruh.

Perkembangan perusahaan bijih timah sehingga mengangkat Tanah Melayu sebagai pengeluar utama di pasaran antarabangsa menuntut penyediaan tenaga kerja yang lebih cekap. Justeru fokus dihalakan kepada penyediaan tenaga kerja alternatif bagi menggantikan tenaga manusia. Serentak dengan kemunculan elektrik sebagai tenaga baharu, pihak kerajaan mula memberi perhatian kepada pembangunannya sebagai salah satu bentuk kemudahan asas. Pada masa yang sama, syarikat swasta juga turut terlibat secara langsung dalam menyediakan kemudahan bekalan elektrik. Peranan yang dimainkan oleh kedua-dua pihak berkenaan telah berjaya membangunkan kemudahan bekalan elektrik untuk dibekalkan kepada penduduk khususnya pengusaha lombong. Keadaan ini membuatkan pengusaha lombong beralih kepada penggunaan elektrik sebagai tenaga kerja dalam menjalankan kerja-kerja melombong bijih timah. Dengan kata lain, berlaku perubahan guna tenaga kerja dalam sektor perlombongan daripada tenaga manusia kepada tenaga yang lebih cekap iaitu elektrik. Tidak dapat dinafikan lagi perubahan kepada tenaga baharu telah memberi kelebihan kepada pengusaha lombong untuk memastikan kelangsungan operasi syarikat.

\section{Perkembangan Awal dan Pengurusan Tenaga Elektrik}

Strategi untuk memastikan kelangsungan perusahaan bijih timah di Lembah Kinta dan Kuala Lumpur yang semakin berkembang pesat bergantung kepada penyediaan tenaga kerja yang mencukupi dan cekap. Keupayaan untuk menyediakannya secara lebih berkesan sejajar dengan keadaan semasa akan memberi keyakinan kepada pemodal untuk terus melabur di samping mengukuhkan lagi perusahaan bijih timah itu sendiri. Kemunculan elektrik sebagai tenaga yang jauh lebih efisien membuatkan usaha untuk membangunkannya diberi perhatian khusus oleh pihak kerajaan mahupun pemain-pemain industri. Walau bagaimanapun, sebelum tahun 1920-an, penyediaan bekalan elektrik sebagai tenaga kerja untuk sektor perlombongan dikendalikan sendiri oleh pengusaha lombong. Hal ini demikian kerana sehingga tempoh tersebut tenaga elektrik merupakan tenaga baharu dan belum mendapat tempat dalam sektor perlombongan mahupun sektor-sektor yang lain.

Pada tahun 1894, Loke Yew dan Thamboosamy Pillai menjadi pengguna tenaga elektrik pertama menerusi pembinaan stesen di lombong bijih timah mereka yang terletak di Rawang, Selangor untuk menggerakkan peralatan mengepam air. ${ }^{7}$ Manakala di Lembah Kinta pula, beberapa pengusaha lombong seperti Society des Etains de Kinta, French Tekkah Company, Idris Hydraulic Tin, Talam Mines dan Society des Etains de Bayas Tudjoh masing-masing menguruskan sendiri stesen janaelektrik untuk menjalankan kerja-kerja mencari gali bijih timah. ${ }^{8}$ Tidak dinafikan pihak kerajaan telah membina stesen janaelektrik di Hulu Gombak pada tahun 1899 untuk menyediakan kemudahan bekalan elektrik kepada pengguna di Kuala Lumpur. Namun perkhidmatan yang dikendalikan oleh Jabatan Kerja Raya (JKR) hanya membekalkan elektrik untuk kegunaan bangunan kerajaan, rumah persendirian dan lampu jalan. 
Kepentingan elektrik sebagai tenaga yang mempunyai pelbagai kegunaan membuatkan pihak kerjaan memberi perhatian khusus kepada pembangunannya. Bagi maksud tersebut, pihak kerajaan melantik Sir Frederick Bolton sebagai Penasihat Elektrik untuk merangka skim pembekalan elektrik di NNMB. ${ }^{9}$ Pada tahun 1921, Bolton mengeluarkan laporan yang mencadangkan pembentukan sebuah organisasi khusus untuk menguruskan perkhidmatan bekalan elektrik. Berdasarkan laporan tersebut, pihak kerajaan mengambil langkah membentuk sebuah sub-department di bawah JKR yang dikenali sebagai Lembaga Elektrik. Sebagai permulaan, Lembaga Elektrik bertanggungjawab menguruskan hal-hal berkaitan dengan pembekalan elektrik di tiga buah bandar utama di NNMB iaitu Kuala Lumpur, Ipoh dan Seremban. Lembaga Elektrik memberi perhatian kepada kerja-kerja menaiktaraf substesen yang sedia ada di sekitar Kuala Lumpur seperti di Ampang, Pudu dan Sentul selain membina sub-stesen baru di Jalan Kia Peng, Jalan Penang dan Jalan Bangsar. Manakala pada tahun 1925, sebuah stesen janaelektrik telah dibina di Bangsar dengan kapasiti 9,000 kW. Sementara itu di Ipoh, Lembaga Elektrik membina sebuah stesen janaelektrik yang dilengkapi dengan tiga set penjana berkapasiti $204 \mathrm{~kW} .{ }^{10}$ Di Seremban pula, Lembaga Elektrik mengambil alih stesen janaelektrik berkapasiti 580 kW daripada United Engineer Limited pada Januari 1924. ${ }^{11}$

Keperluan untuk membangunkan kemudahan bekalan elektrik dengan lebih efektif menyebabkan pihak kerajaan mengstrukturkan sistem pengurusannya. Hasilnya pada tahun 1927, Jabatan Elektrik diwujudkan sebagai jabatan federal bagi menggantikan Lembaga Elektrik. Pengstrukturan ini menjadikan perkhidmatan bekalan elektrik di NNMB lebih sistematik. Berbeza dengan Lembaga Elektrik yang dianggotai oleh pengarah JKR, General Manager, Railways dan Senior Warden of Mines, kakitangan yang dilantik untuk menguruskan Jabatan Elektrik mempunyai kepakaran dalam bidang kejuruteraan elektrik. Misalnya W.J. William yang dilantik sebagai pengarah mempunyai kelulusan dari University College of North Wales dan berpengalaman dalam menguruskan pembangunan kemudahan bekalan elektrik. ${ }^{12}$ Merujuk kepada aspek pembangunan pula, Jabatan Elektrik memberi perhatian kepada sebahagian besar kawasan di NNMB seperti Kuala Lumpur, Klang, Kuala Kubu Bharu dan Rawang di Selangor; Taiping, Tanjung Rambutan dan Tanjung Malim di Perak; Seremban, Gemas dan Port Dickson di Negeri Sembilan; Raub, Bentong dan Kuala Lipis di Pahang.

Pengstrukturan semula pengurusan bekalan elektrik oleh pihak kerajaan telah menjadi pemangkin kepada proses pembangunan kemudahan asas tersebut dengan lebih menyeluruh melibatkan segenap aspek kepenggunaan sama ada untuk sektor ekonomi, domestik dan awam. Sesuai dengan perkembangan perusahaan bijih timah di NNMB, Jabatan Elektrik memberi perhatian kepada penyediaan bekalan elektrik untuk kegunaan pengusaha lombong. Walau bagaimanapun, perkhidmatan yang disediakan oleh Jabatan Elektrik hanya tertumpu di sekitar Kuala Lumpur sahaja yang merupakan pusat perlombongan utama di Selangor. Selain membina stesen janaelektrik dan sistem pembekalannya, Jabatan Elektrik turut membina mining substation di kawasan perlombongan bijih timah yang dikhususkan untuk membekalkan tenaga elektrik kepada pengusaha lombong. Contohnya pada tahun 1928,sebanyak 11 buah mining sub-station telah dibina untuk membekalkan elektrik kepada pengusaha lombong. ${ }^{13}$ Pembinaannya telah memudahkan para pengusaha mendapatkan bekalan elektrik bagi menjalankan kerja-kerja melombong bijih timah. Selain itu, tumpuan diberikan kepada penyambungan talian penghantaran untuk meluaskan rangkaian pembekalan elektrik sekali gus membolehkan lebih banyak pengusaha lombong mendapat bekalan elektrik. Misalnya kerja-kerja penyambungan talian penghantaran 
dibuat dari Sentul ke Kepong untuk membekalkan elektrik kepada Kepong Tin Dredge. ${ }^{14}$ Menjelang tahun 1928, talian penghantaran kemudiannya dihubungkan ke Sione dan Batu Caves Tin Dredge Company. ${ }^{15}$ Pada masa yang sama, talian penghantaran 33,000 volt telah dihubungkan dari Jalan Sungai Besi ke Serdang sebelum disambungkan ke Lombong Tet Lee, Weng Loong dan Hock Hin. ${ }^{16}$ Manakala talian penghantaran 11,000 volt disambungkan ke Lombong Kat Loong, Goh Thean Sang, Chop Heap Loong di kawasan Pudu Ulu. ${ }^{17}$

Sementara itu, bagi pengusaha lombong di Perak khususnya Lembah Kinta, kemudahan bekalan elektrik disediakan oleh sebuah syarikat swasta iaitu Perak River Hydro Electric Power Company (PRHEPC). Kedudukan Lembah Kinta sebagai pusat perlombongan bijih timah yang utama di Perak mahupun Tanah Melayu menyebabkan pihak kerajaan merangka strategi untuk membangunkan kemudahan bekalan elektrik dengan lebih efektif. Oleh itu satu keputusan telah diambil untuk membangunkan stesen hidro elektrik menerusi perlaksanaan Skim Hidro Elektrik Sungai Perak (SHESP). Walau bagaimanapun, masalah kewangan yang dihadapi menyukarkan pihak kerajaan untuk melaksanakan skim tersebut. Didapati pendapatan yang diperoleh NNMB pada tahun 1921 hanya $\$ 73,450,779$ berbanding perbelanjaannya $\$ 101,426,220$. Pada tahun 1922 , jumlah perbelanjaan yang dikeluarkan sebanyak $\$ 67,151,142$ mengatasi hasil pendapatannya kira-kira $\$ 59,818,670 .{ }^{18}$ Kesungguhan untuk merealisasikan SHESP mendorong pihak kerajaan menawarkan konsesi kepada syarikat swasta sehingga menarik minat Sir Armstrong Whitworth \& Company.

Penyerahan konsesi telah dilaksanakan menerusi perjanjian yang ditandatangani dengan Kerajaan Perak pada tahun 1925 yang membawa kepada penubuhan PRHEPC pada tahun berikutnya sebagai pemaju kepada SHESP. ${ }^{19}$ Serentak dengan itu, PRHEPC turut dipertanggungjawabkan untuk menguruskan penyediaan kemudahan bekalan elektrik kepada perusahaan bijih timah di Lembah Kinta dan pengguna domestik di beberapa kawasan sekitar Perak. Antaranya di Daerah Kuala Kangsar; Mukim Durian Pipit, Temelong dan Lenggor dibahagian hulu Perak; Daerah Kinta; Mukim Chenderiang, Batang Padang dan Bidor di Daerah Batang Padang; Mukim Pulau Tiga, Kampung Gajah dan Panjang Ulu di bahagian hilir Perak. ${ }^{20}$

Sejajar dengan matlamat penubuhannya untuk menjayakan SHESP, PRHEPC mula menjalankan kerja-kerja pembinaan stesen hidro elektrik di Chenderoh dengan kapasiti penjanaan 27,000 kW pada tahun 1927 sebelum memulakan operasi secara rasmi pada tahun $1930 .^{21}$ Pembinaan Stesen Hidro Elektrik Chenderoh telah mengangkat PRHEPC sebagai pemilik stesen hidro elektrik terbesar di Tanah Melayu sekali gus membawa perkhidmatan bekalan elektrik di Perak ke tahap yang termaju. Bagi memastikan keberkesanan dalam perkhidmatannya, PRHEPC mengambil langkah membina sebuah stesen janaelektrik di Malim Nawar dengan kapasiti penjanaan sehingga $18,000 \mathrm{~kW} \cdot{ }^{22}$ Kedua-dua stesen berkenaan kemudiannya dihubungkan dengan sub-stesen $22 \mathrm{kV}$ yang terletak di Temoh, Kampar,Petaling, Tanjong Toh Alang, Tronoh, Batu Gajah, Papan dan Menglembu serta sub-stesen 66 kV di Selibin dan Talang Pamaya. ${ }^{23}$ Penyambungan yang dilakukan ini membolehkan tenaga elektrik yang dijana menerusi kedua-dua stesen penjanaan milik PRHEPC dibekalkan kepada semua pengguna di kawasan konsesi termasuklah pengusaha lombong bijih timah.

Berdasarkan perkhidmatan bekalan elektrik di Perak dan Selangor, jelas menunjukkan wujud kerjasama antara pihak kerajaan dengan syarikat swasta. Walaupun pihak kerajaan telah menubuhkan Jabatan Elektrik untuk menguruskan 
pembangunan kemudahan bekalan elektrik di NNMB, namun perkhidmatan daripada syarikat swasta seperti PRHEPC masih lagi diperlukan dalam konteks penyediaan tenaga elektrik untuk perusahaan bijih timah. Penglibatan kedua-dua pihak berkenaan menjadi tunjang kepada perkembangan kemudahan bekalan elektrik yang seterusnya memberi manfaat kepada pengusaha lombong untuk meningkatkan kecekapan pengurusan operasi lombong bijih timah.

\section{Penggunaan Tenaga Elektrik Dalam Industri Bijih Timah}

Secara umumnya, penggunaan tenaga elektrik di NNMB lebih tertumpu kepada sektor perlombongan bijih timah berbanding untuk kegunaan domestik dan awam. Malah sebaik sahaja teknologi kejuruteraan elektrik diperkenalkan di negeri-negeri Melayu, pengusaha lombong telah menunjukkan kecenderungan untuk menggunakannya bagi menggantikan tenaga buruh. Walau bagaimanapun, proses peralihan kepada tenaga elektrik berlaku secara berperingkat-peringkat. Misalnya tempoh sehingga awal abad ke-20, didapati pengusaha lombong masih lagi menjadikan tenaga buruh sebagai sumber tenaga untuk menjalankan aktiviti melombong bijih timah. Hal ini demikian kerana tenaga elektrik sehingga tempoh tersebut masih lagi berada pada peringkat awal pembangunan dan hanya terhad di kawasan-kawasan tertentu sahaja. Tambahan pula proses pembinaan stesen janaelektrik dan sistem pembekalannya mengambil masa dan melibatkan penggunaan modal yang besar serta kepakaran yang khusus. Justeru sukar untuk syarikat perlombongan menguruskan sendiri penyediaan bekalan elektrik.

Menjelang pertengahan tahun 1920-an, didapati penggunaan tenaga elektrik mula menunjukkan peningkatan. Tidak dinafikan terdapat sumber tenaga alternatif seperti steam, hydraulic, sution gas dan oil engine yang turut digunakan sebagai tenaga kerja dalam perusahaan bijih timah bagi menggantikan tenaga buruh. Namun kemajuan dalam penyediaan kemudahan bekalan elektrik membuatkan penggunaannya lebih 'popular' dan menjadi pilihan utama pengusaha lombong bijih timah di Perak dan Selangor. 


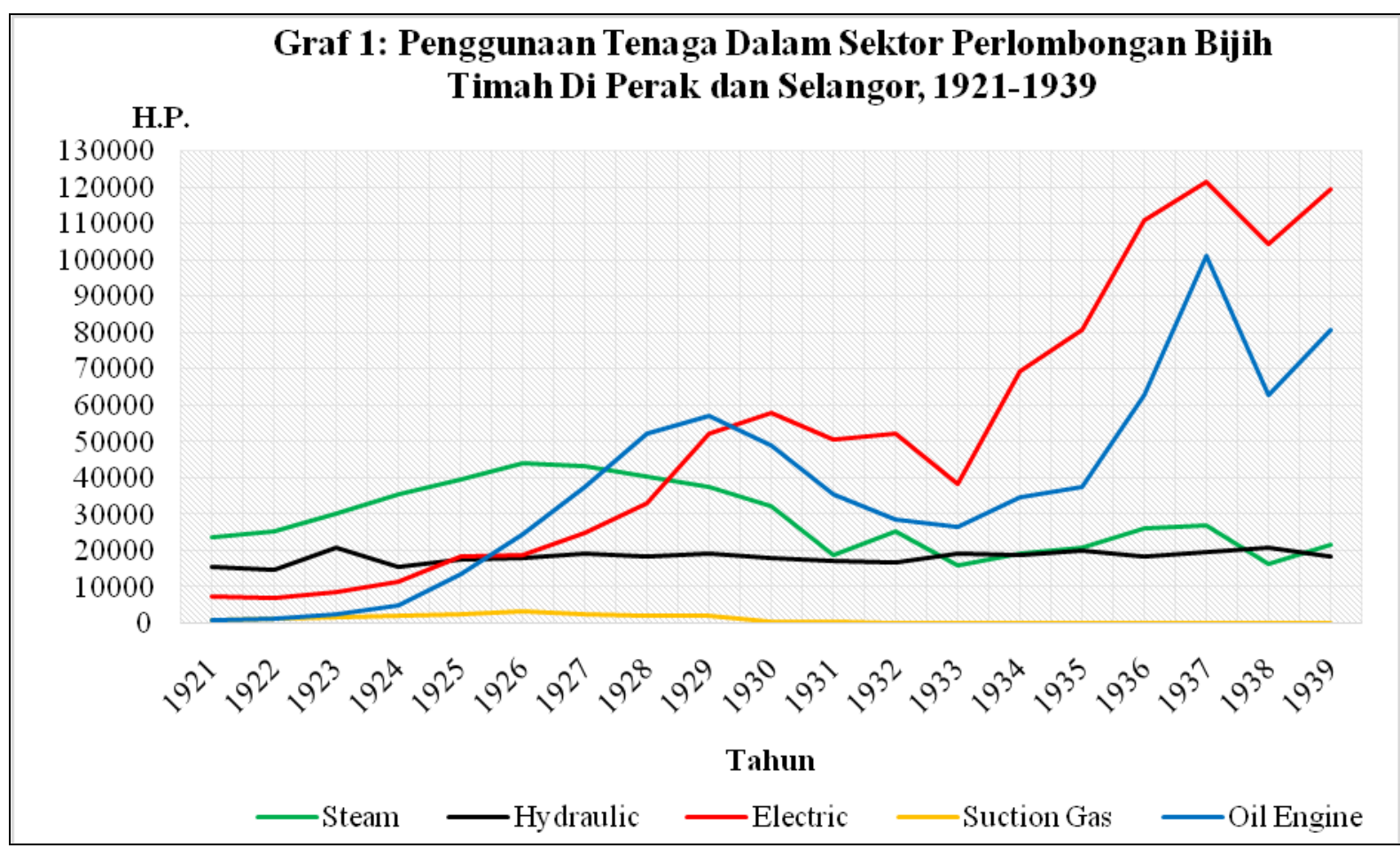

Sumber: Disesuaikan daripada Report on the Administration of the Mines Department and on the Mining Industries, 1921-1939.

Berdasarkan Graf 1, didapati penggunaan tenaga elektrik mula menunjukkan peningkatan yang drastik memasuki tahun 1927 sebelum mengatasi sumber tenaga yang lain menjelang tahun 1930. Hal ini disebabkan perkhidmatan bekalan elektrik yang disediakan oleh Jabatan Elektrik dan PRHEPC. Keupayaan kedua-dua pihak berkenaan membangunkan kemudahan bekalan elektrik sejajar dengan keperluan semasa telah memudahkan pengusaha-pengusaha lombong khususnya di dua pusat perlombongan yang utama iaitu Lembah Kinta dan Kuala Lumpur mendapatkan bekalan elektrik.

Langkah yang diambil oleh Jabatan Elektrik dengan membina mining substation yang dikhususkan untuk membekalkan elektrik kepada kawasan perlombongan di Kuala Lumpur mulai tahun 1927 menyebabkan sebahagian besar syarikat perlombongan beralih kepada penggunaan tenaga elektrik. Sementara itu Stesen Janaelektrik Malim Nawar dan Stesen Hidro Elektrik Chenderoh milik PRHEPC yang memulakan operasi masing-masing pada tahun 1928 dan 1930 membolehkan tenaga elektrik dibekalkan kepada pusat perlombongan di Lembah Kinta. Dengan kata lain, perkhidmatan kedua-dua pihak berkenaan yang jelas mengutamakan keperluan pengguna dalam sektor perlombongan bijih timah membuatkan penggunaan tenaga elektrik semakin mendapat tempat dalam kalangan pengusaha lombong bijih timah.

Tidak dinafikan penggunaan tenaga elektrik mencatatkan penurunan pada tahun 1931 sehingga tahun 1933. Keadaan ini berlaku bukan disebabkan masalah dalam pembekalan elektrik sebaliknya berpunca daripada kemerosotan sektor perlombongan bijih timah sehingga memberi kesan kepada penggunaan tenaga elektrik. Masalah kemelesetan ekonomi dunia yang berlaku semasa tempoh tersebut telah memberi kesan langsung kepada sektor perlombongan bijih timah di Tanah Melayu khususnya di Selangor dan Perak. Negara-negara pengimport mengurangkan pengimportan bijih timah sekali gus menyebabkan pengeluarannya melebihi 
permintaan. Serentak dengan itu, harga pasaran bijih timah menunjukkan penurunan daripada $£ 206$ satu tan pada tahun 1929 kepada $£ 143$ satu tan pada tahun berikutnya. ${ }^{24}$ Didapati harga pasaran bijih timah terus mengalami penurunan kepada $£ 120$ satu tan pada tahun $1931 .^{25}$

Bagi mengatasi masalah tersebut, Perjanjian Timah Antarabangsa telah dikuatkuasakan pada tahun 1931 sehingga 1933 yang menuntut negara pengeluar menghadkan kuota pengeluaran untuk menstabilkan harga bijih timah. ${ }^{26}$ Perlaksanaannya memberi kesan langsung kepada Selangor dan Perak yang merupakan penyumbang terbesar kepada pengeluaran bijih timah di Tanah Melayu. Pasaran bijih timah yang tidak memberangsangkan ini membuatkan pengusaha lombong menghadkan aktiviti mereka seterusnya mempengaruhi penggunaan tenaga elektrik. Misalnya pada tahun 1933, terdapat 70 buah lombong bijih timah beroperasi menggunakan kapal korek dan daripada jumlah tersebut hanya 11 buah lombong meneruskan operasi seperti biasa. ${ }^{27}$ Memasuki tahun 1934, penggunaan tenaga elektrik dalam sektor perlombongan bijih timah memperlihatkan peningkatan. Hal ini disebabkan tindakan pengusaha lombong yang kembali menggunakan tenaga elektrik untuk menjalankan kerja-kerja mencari gali bijih timah sebaik sahaja masalah kemelesetan ekonomi beransur pulih di samping peningkatan harga pasaran bijih timah.

\section{Kepentingan Tenaga Elektrik Kepada Industri Bijih Timah}

\section{Penyediaan Tenaga Alternatif}

Pembangunan kemudahan bekalan elektrik telah memberi jaminan kepada penyediaan tenaga kerja yang lebih stabil dan mencukupi untuk memastikan kelancaran operasi perusahaan bijih timah. Penyediaan tenaga elektrik dilihat bertepatan dengan masalah kekurangan tenaga buruh yang dialami oleh pengusaha lombong. Tidak dinafikan sehingga awal abad ke-20, keperluan tenaga buruh untuk sektor perlombongan bijih timah masih lagi terjamin kerana sebahagian besar buruh Cina yang dibawa masuk ke Tanah Melayu khususnya Perak dan Selangor digunakan oleh pengusaha lombong untuk menjalankan kerja-kerja melombong bijih timah. Namun memasuki dekad terawal abad ke-20, penggunaan tenaga buruh Cina telah dipelbagaikan untuk pembinaan jalan raya, landasan kereta api, penarik beca dan sebagainya. ${ }^{28}$ Malah buruh Cina juga mula digunakan untuk mengusahakan sektor pertanian. Misalnya perkembangan tanaman getah membuatkan pengusaha Eropah menggunakan buruh Cina untuk menguruskan kerja-kerja di ladang getah. ${ }^{29}$

Selain itu, perubahan peraturan berkaitan dengan buruh dan sektor perlombongan turut memberi kesan kepada penyediaan tenaga kerja dalam kalangan pengusaha lombong khususnya pengusaha Cina. Misalnya pemansuhan pajakan candu di Perakpada 1 Januari 1895 dan Selangor pada 1 Januari $1900 .{ }^{30}$ Keadaan ini menyebabkan pengusaha Cina kehilangan modal penting sekali gus menyukarkan mereka untuk mengupah tenaga buruh dalam kuantiti yang ramai.Sebelum pemansuhan pajakan candu, pengusaha lombong diberi hak untuk menguruskan halhal berkaitan dengan penjualan candu. Kesempatan ini telah digunakan oleh pengusaha lombong untuk memanipulasi tenaga buruh supaya terus bekerja di lombong milik mereka. Penjualan candu di kawasan perlombongan dan pembeliannya secara kredit mendedahkan buruh dengan masalah hutang. Keadaan ini menyebabkan buruh terikat dengan pengusaha lombong untuk tempoh yang lama dan perlu bekerja di lombong berkenaan sehingga hutangnya selesai. Namun pengambilalihan hak 
mengimport dan menjual candu oleh pihak kerajaan menerusi penguatkuasaan Federal Coast Chandu Enactment pada tahun 1909 telah menghalang pengusaha lombong untuk terus mengeksploitasi tenaga buruh. Dengan kata lain, pengusaha lombong tidak lagi mempunyai hak untuk mengawal dan menguasai tenaga buruh.

Keadaan ini secara tidak langsung menyumbang kepada masalah kekurangan tenaga buruh. Contohnya, pada tahun 1927 terdapat seramai 114,640 buruh terlibat dalam industri bijih timah di Perak dan Selangor. ${ }^{31}$ Dalam tempoh tiga tahun berikutnya, bilangan buruh mencatatkan penurunan kepada 74,164 orang sebelum menurun kepada 38,188 orang menjelang tahun 1933. ${ }^{32}$ Walaupun mengalami masalah kekurangan tenaga buruh, namun pengusaha lombong masih lagi mampu untuk menjalankan kerja-kerja melombong bijih timah. Hal ini tidak lain adalah disebabkan kemajuan dalam penyediaan bekalan elektrik sebagai tenaga alternatif untuk industri bijih timah. Didapati pengusaha-pengusaha lombong mengambil langkah beralih kepada penggunaan tenaga elektrik yang disediakan oleh Jabatan Elektrik mahupun PRHEPC. Malah penggunaannya sebagai tenaga alternatif menjadikan kerja-kerja melombong lebih cekap. Hal ini demikian kerana, setiap satu horse power (h.p.) tenaga elektrik yang digunakan mampu menjalankan kerja melombong bersamaan dengan tenaga kerja bagi lapan orang buruh.

Menerusi perkhidmatan yang disediakan oleh Jabatan Elektrik, penggunaan tenaga elektrik dalam industri bijih timah di Selangor mula menunjukkan peningkatan. Pada tahun 1927, sebanyak 7,580 h.p. tenaga elektrik digunakan sebelum meningkat kepada 17,211 h.p. menjelang tahun $1930 .{ }^{33}$ Dalam tempoh lima tahun berikutnya, penggunaan tenaga elektrik terus mencatatkan peningkatan kepada 26,245 h.p. ${ }^{34}$ Di sebalik peningkatan ini menunjukkan pengusaha lombong di Kuala Lumpur mula beralih kepada penggunaan tenaga elektrik bagi menampung kekurangan tenaga buruh. Misalnya Lombong Long Tong Lee dan Low Tai Kok beralih kepada penggunaan tenaga elektrik sebaik sahaja Jabatan Elektrik membina mining sub-station pada tahun $1927 .{ }^{35}$ Begitu juga dengan Lombong Lam Looking, Toong Loy, Poh Chong dan Hong Fatt Mine yang mula menggunakan elekrik menjelang tahun 1930-an. ${ }^{36}$ Penggunaannya berupaya meningkatkan kecekapan kerjakerja mencari gali bijih timah seterusnya meningkatkan lagi hasil pengeluarannya. Walaupun tenaga buruh menunjukkan penurunan antara tahun 1927 sehingga 1930, namun peralihan kepada tenaga elektrik membuatkan hasil pengeluaran bijih timah bagi tempoh tersebut masih lagi menunjukkan peningkatan. Contohnya pada tahun 1929, hasil pengeluaran bijih timah mencatatkan peningkatan kepada 19,449 tan berbanding 12,716 tan pada tahun $1927 .{ }^{37}$ Tidak dinafikan pengeluaran bijih timah menunjukkan penurunan sekitar tahun 1930-an. Misalnya pada tahun 1930, pengeluaran bijih timah mencatatkan penurunan kepada 17,960 tan sebelum terus menunjukkan penurunan kepada 7,133 tan pada tahun $1933 .^{38}$

Sementara itu, bagi pengusaha lombong di Lembah Kinta pula, kekurangan tenaga buruh telah ditampung dengan menggunakan tenaga elektrik yang disediakan oleh PRHEPC. Pembinaan Stesen Hidro Elektrik Chenderoh dan Stesen Janaelektrik Malim Nawar dengan kapasiti penjanaan yang besar memastikan keperluan tenaga elektrik dalam kalangan pengusaha lombong sentiasa mencukupi. Penyediaannya sebagai tenaga alternatif membuatkan pengusaha lombong seperti Society des Etains de Kinta, Kinta Tin Dredging, Tujoh Tin No Liability, Penawat (Malaya) Tin Dredging, Malaya Tin Dredging dan Malim Nawar Tin menandatangani perjanjian dengan PRHEPC untuk mendapatkan bekalan elektrik. ${ }^{39}$ Didapati bilangan pengusaha lombong yang mendapatkan bekalan elektrik daripada PRHEPC menunjukkan peningkatan daripada 24 buah lombong pada tahun 1929 kepada 27 buah lombong 
pada tahun berikutnya. ${ }^{40}$ Memasuki tahun 1933, sebanyak 66 buah lombong telah dibekalkan dengan tenaga elektrik oleh PRHEPC berbanding 47 buah lombong pada tahun $1932 .{ }^{41}$ Sehingga tahun 1939 , penggunaan tenaga elektrik dalam perusahaan bijih timah di Perak mencecah 84,913 h.p. berbanding 54,803 h.p. pada tahun $1935 .{ }^{42}$

\section{Pemodenan Kaedah Melombong}

Penggunaan bekalan elektrik sebagai tenaga kerja telah membantu proses pemodenan sektor perlombongan bijih timah. Hal ini bertepatan dengan dasar ekonomi pihak kerajaan yang memberi galakan kepada pengusaha lombong supaya memodenkan kaedah melombong menerusi penggunaan jentera. ${ }^{43}$ Berbanding dengan tenaga buruh, kerja-kerja melombong bijih timah dibuat menggunakan peralatan yang ringkas seperti cangkul, bakul rotan, kayu dan sebagainya. Penggunaan peralatan tersebut memerlukan pengusaha merekrut tenaga buruh dalam kuantiti yang ramai untuk membolehkan sesebuah lombong itu diusahakan. Tidak dinafikan sehingga awal abad ke-20 tiada halangan bagi pengusaha lombong untuk menggunakan tenaga buruh. Namun masalah kekurangan tenaga buruh yang berlaku pada tahun-tahun berikutnya dan ditambah pula dengan kedudukan Tanah Melayu sebagai pengeluar bijih timah utama di pasaran antarabangsa menyebabkan pergantungan kepada tenaga buruh tidak lagi relevan. Sebaliknya pengusaha lombong perlu memperbaharui kaedah melombong untuk memastikan pengeluaran hasil bijih timah sejajar dengan permintaan.

Kemudahan bekalan elektrik yang disediakan oleh Jabatan Elektrik dan PRHEPC memberi ruang kepada pengusaha lombong untuk menambahbaik kaedah melombong dengan menggunakan jentera seperti kapal korek. Kaedah ini menjadikan kerja-kerja melombong bijih timah lebih berkesan tanpa melibatkan tenaga buruh yang ramai. Menerusi penggunaan kapal korek membolehkan karang digali dan dibawa terus ke permukaan di dalam bakul yang ditarik dengan rantai sebelum dihancurkan dengan mesin untuk memisahkan bijih timah dengan tanah. Seterusnya sisa seperti tanah akan dibuang terus ke tempat yang khusus untuk memudahkan buruh mengambil hasil bijih timah yang telah diasingkan. ${ }^{44}$ Pengenalan kapal korek ini sangat penting bagi pengusaha lombong di sekitar Lembah Kinta. Hal ini demikian kerana hasil bijih timah di kawasan permukaan sehingga kedalaman kurang daripada 15 kaki semakin berkurangan. ${ }^{45}$ Keadaan ini memerlukan pengusaha lombong menggali dengan lebih dalam lagi untuk mendapatkan bijih timah. Tambahan pula peralatan seperti mesin hydraulic dan gravel-pump tidak sesuai untuk digunakan di kawasan lombong yang berair. ${ }^{46}$ Didapati sebahagian besar pengusaha lombong di Perak berupaya mengaplikasikan teknologi moden dalam melombong bijih timah menerusi bekalan elektrik yang disediakan oleh PRHEPC. Antaranya Jelapang Tin Dredging Ltd., Kramat Tin Dredging Ltd., Lower Perak Tin Dredging Ltd., Malayan Tin Dredging Ltd., dan Southern Kinta Consolidated Ltd. ${ }^{47}$

Sementara itu, bagi pengusaha Cina yang kebanyakannya mengusahakan lombong dedah, penyediaan bekalan elektrik membolehkan mereka beralih kepada penggunaan motor elektrik menggantikan enjin diesel yang bersaiz besar. Secara umumnya, kaedah chain pump yang digunakan oleh pengusaha Cina untuk menjalankan kerja-kerja mencari gali bijih timah terhad pada kedalaman kurang daripada 15 kaki. Keperluan untuk meningkatkan hasil pengeluaran memerlukan pengusaha menggali dengan lebih dalam lagi antara 30 hingga $50 \mathrm{kaki}^{48}$ Penggunaan enjin diesel bersaiz besar menyukarkan pengusaha untuk mengalihnya mengikut kedalaman lombong kerana perlu mengambil kira ruang dan struktur tanah. ${ }^{49}$ Keadaan 
ini menyebabkan pengusaha Cina mula beralih kepada penggunaan motor elektrik yang bersaiz kecil. Tambahan pula Jabatan Elektrik dan PRHEPC turut menyediakan khidmat sewaan motor elektrik kepada pengusaha lombong. Pada tahun 1930, Jabatan Elektrik telah menyewa empat buah motor elektrik kepada pengusaha lombong di Kuala Lumpur. ${ }^{50}$ Keberkesanan motor elektrik dalam membantu proses mencari gali bijih timah menyebabkan permintaannya semakin meningkat. Menjelang tahun 1935, sebanyak 81 buah motor elektrik telah disewakan oleh Jabatan Elektrik sebelum meningkat kepada 92 buah pada tahun 1939. ${ }^{51}$ Sementara itu di Perak pula, PRHEPC telah membekalkan tenaga elektrik kepada beberapa pengusaha lombong dedah sepertiChan Tat Cho, Wong Peng Sam, Choo Hoy, Wong Seong, Loke Man Choke, Leong Mong Chew, Wan Fook, Hah Liew Yee, Chen Yoong Seong, Leow Yee Thong, Lai Weng Huin, Chong Foong, Keat Hock Tong Mining Kongsi, Yap Chin, Lim Boon Haw dan Tai Chee Show. ${ }^{52}$ Keadaan ini membuatkan para pengusaha mula menjalankan operasi menggunakan motor elektrik yang turut disediakan oleh PRHEPC. ${ }^{53}$

\section{Penjimatan Kos Operasi}

Peralihan kepada penggunaan tenaga elektrik menjadikan operasi syarikat perlombongan lebih ekonomik. Walaupun pembangunan kemudahan asas tersebut memerlukan modal yang besar, namun pengusaha lombong tidak terlibat dalam penyediaannya. Berbanding beroperasi menggunakan tenaga buruh, pengusaha lombong perlu mengeluarkan perbelanjaan yang besar untuk menampung kos pengambilan buruh dan menyediakan kemudahan asas seperti tempat tinggal, bekalan air, makanan dan sebagainya. Selain itu, pengusaha lombong juga bertanggungjawab menjaga kebajikan buruh dan membayar kos perubatan serta rawatan sekiranya buruh dimasukkan ke hospital kerajaan. ${ }^{54}$ Begitu juga dengan penggunaan tenaga kerja yang dihasilkan menerusi proses pembakaran memerlukan pengusaha lombong menanggung kos kendalian untuk membeli bahan bakar seperti arang batu dan diesel di samping penyelenggaraan stesen.

Menerusi penggunaan tenaga elektrik, pengusaha lombong hanya perlu mengeluarkan perbelanjaan bagi pembelian unit tenaga yang diperlukan untuk menjalankan kerja-kerja melombong. Hal ini demikian kerana modal untuk membina stesen janaelektrik dan sistem pembekalan serta kos kendalian untuk menjana tenaga elektrik ditanggung sepenuhnya oleh Jabatan Elektrik dan PRHEPC. Kemudahan yang disediakan ini mendorong pengusaha lombong memilih untuk mendapatkan terus tenaga elektrik daripada pihak pembekal. Misalnya, Society des Etains de Kinta yang pada mulanya menjana sendiri tenaga elektrik mengambil langkah mendapatkan bekalan elektrik daripada PRHEP. ${ }^{55}$ Manakala Lombong Cheong Hin yang menggunakan enjin diesel untuk menggerakkan pam kerikil mula beralih kepada penggunaan tenaga elektrik dan motor elektrik yang disediakan oleh Jabatan Elektrik. $^{56}$

Selain penjimatan kos dari segi penyediaan tenaga kerja, penggunaan bekalan elektrik juga membolehkan pengusaha lombong menjalankan kerja-kerja melombong bijih timah pada kos yang lebih murah. Bagi pengusaha lombong yang beroperasi menggunakan kapal korek, kos untuk mencari gali bijih timah lebih rendah berbanding pengusaha lombong yang menggunakan kaedah pam kerikil dan 
sebagainya. Contohnya, Malayan Tin Dredging Company hanya mengeluarkan kos sebanyak 16 sen bagi setiap cubic karang. Sementara itu, Pengkalen Limited yang beroperasi menggunakan pam kerikil mengeluarkan kos sebanyak 57 sen bagi setiap cubic karang yang digali. Manakala Tambun Mines dan Lahat Mines yang mengusahakan lombong dedah masing-masing mengeluarkan modal sebanyak 61 sen dan 94 sen untuk setiap cubic karang. ${ }^{57}$

Menerusi penggunaan bekalan elektrik, pengusaha lombong berupaya untuk menentukan kos pengurusan sejajar dengan harga pasaran bijih timah. Semasa kejatuhan harga bijih timah, pengusaha lombong hanya perlu membuat permohonan kepada pihak pembekal untuk mengurangkan kapasiti penjanaan tenaga elektrik di lombong sekali gus dapat menjimatkan perbelanjaan operasi. Perjanjian Timah Antarabangsa yang menuntut negara pengeluar seperti Tanah Melayu untuk mematuhi kuota pengeluaran bijih timah menyebabkan beberapa pengusaha menghadkan kerjakerja melombong. Serentak dengan itu, pengusaha lombong di sekitar Kuala Lumpur sama ada yang mengusahakan lombong dedah mahupun menggunakan kapal korek memohon kepada Jabatan Elektrik supaya mengurangkan pembekalan elektrik. ${ }^{58}$ Contohnya pengusaha lombong Soon Aik dan Choong Hing masing-masing mengurangakan kapasiti penjanaan daripada 600 KVA kepada 400 KVA. Manakala pengusaha lombong Hock Hin pula memohon Jabatan Elektrik mengurangkan kapasiti penjanaan daripada $500 \mathrm{KVA}$ kepada $300 \mathrm{KVA} .{ }^{59}$ Terdapat juga pengusaha lombong seperti Hon Lee, Ying Tong, Ban Hoe, Ban Huat dan Weng Fatt memohon supaya Jabatan Elektrik memberhentikan buat sementara waktu pembekalan elektrik di lombong mereka berikutan kejatuhan harga bijih timah. ${ }^{60}$

\section{Kesimpulan}

Penyediaan kemudahan bekalan elektrik sebagai sumber tenaga untuk kegunaan pengusaha lombong telah memberi dimensi baru kepada perkembangan industri bijih timah di Kuala Lumpur dan Lembah Kinta. Kepentingan elektrik sebagai tenaga kerja yang lebih efisien untuk perusahaan bijih timah menyebabkan pihak kerajaan memberi perhatian khusus kepada pembangunannya. Menerusi Jabatan Elektrik, tumpuan diberikan kepada pembinaan mining sub-station bagi memastikan pengusaha lombong mendapat bekalan elektrik untuk menjalankan kerja-kerja melombong bijih timah. Keperluan untuk menyediakan bekalan elektrik kepada perusahaan bijih timah di Lembah Kinta pula telah mendorong pihak kerajaan menyerahkan tanggungjawab tersebut kepada PRHEPC. Perkhidmatan yang disediakan oleh kedua-dua pihak menyebabkan berlaku perubahan corak tenaga kerja daripada berintensifkan tenaga buruh kepada tenaga yang lebih cekap iaitu elektrik. Walau bagaimanapun, kecekapan tenaga elektrik tidak diukur dari segi peningkatan hasil pengeluaran bijih timah. Sebaliknya kepentingan tenaga elektrik dinilai menerusi penyediaannya sebagai tenaga kerja alternatif bagi mengatasi masalah kekurangan tenaga buruh yang dihadapi oleh pengusaha-pengusaha lombong. Ternyata kemudahan bekalan elektrik yang disediakan telah memenuhi keperluan tenaga kerja dalam industri bijih timah seterusnya membolehkan pengusaha lombong meneruskan operasi mereka. Keadaan ini menjadikan kos operasi syarikat perlombongan lebih ekonomik kerana keperluan terhadap tenaga elektrik disediakan sepenuhnya oleh pihak pembekal. Peralihan kepada tenaga elektrik kemudiannya telah membuka ruang kepada pengusaha 
lombong untuk mempelbagaikan lagi kaedah melombong menerusi penggunaan jentera yang lebih canggih. Kaedah ini membolehkan pengusaha lombong menjalankan kerja-kerja mencari gali bijih timah dengan lebih berkesan khususnya di bahagian dasar lombong.Ringkasnya, perkembangan kemudahan bekalan elektrik telah memberi jaminan kepada kelangsungan perusahaan bijih timah di Kuala Lumpur dan Lembah Kinta dan membawanya ke arah yang lebih moden.

\footnotetext{
Nota

*Penghargaan: Peruntukan untuk menjalankan penulisan ini diperoleh daripada Universiti Malaya menerusi Geran BKS 014-2018.

1 J.G. Butcher, "The Demise of the Revenue Farm System in the Federated Malay States", Modern Asian Studies, Vol. 17, No. 3, 1983, h. 388.

2 P.J. Drake, "The Economic Development of British Malaya to 1914: An Essay in Historiography with Some Questions for Historians", Journal of Southeast Asian Studies, Vol. 10, No. 2, 1979, h. 277. Frank Swettenham, British Malaya: An Account of the Origin and Progress of British Influence in Malaya, London: John Lane The Bodley Head, 1906, h. 294.

$4 \quad$ Wong Lin Ken, The Malayan Tin Industry To 1914, Tucson: The University of Arizona Press, 1965, h. 87-90.

Perak Administration Report for the year 1910, h. 9.

Wong Lin Ken, The Malayan Tin Industry To 1914, h. 175.

Sumangala Pillai, Tenaga Penggerak Kemajuan, Selangor: Tenaga Nasional Berhad, t.t., h. 14.

F.T. Ingham \& E.F. Bradford, The Geology and Mineral Resources of the Kinta Valley, Perak, Kuala Lumpur: Government Press, 1960, h. 103.

HCO 2530/1919, Engagement of Mr F. Bolton as Expert Adviser on Electric.

Annual Report of the Electrical Board for the year 1925, h. 8.

Annual Report of the Electrical Board for the year 1924, h. 8.

C.O. 717/53/17997, Creation of Separate Electrical Department and Appoint of Independent Head, h. 12-13; Muzaffar Tate, Power Builds The Nation: The National Electricity Board of the States of Malaya and Its Predecessors, Kuala Lumpur: The National Electricity Board of the States of Malaya, 1989, h. 128.

13 Annual Report and Accounts of the Electrical Department for the year 1928, h. 6.

Annual Report and Accounts of the Electrical Department for the year 1927, h. 2.

Annual Report and Accounts of the Electrical Department for the year 1928, h. 6.

Ibid.

Ibid.

Ahmad Kamal Ariffin Mohd Rus, 'Perkembangan Majlis Mesyuarat Persekutuan, 19091927', Tesis Phd., Jabatan Sejarah, Fakulti Sastera dan Sains Sosial, Universiti Malaya, Kuala Lumpur, 2006, h. 270.

Annual Report and Accounts of the Electrical Board for the year 1926, h. 1.

C.O. 717/65/62367/C, Perak River Hydro-Electric Company, h. 8.

Muzaffar Tate, Power Builds The Nation: The National Electricity Board of the States of Malaya and Its Predecessors, h. 237.

22 Annual Report and Accounts of the Electrical Department for the year 1927, h. 1.

23 B.M. Hellstrom, The Perak River Hydro-Electric Power Scheme, London: Great George Street, 1934, h. 57. Report on the Administration of the Mines Department and on the Mining Industries, 1930, h. 5. Report on the Administration of the Mines Department and on the Mining Industries, 1931, h. 5.

Yip Yat Hoong, The Development of the Tin Mining Industry of Malaya, Kuala Lumpur: University of Malaya Press, 1965, h. 187-188. 14.

Wong Lin Ken, The Malayan Tin Industry To 1914, h. 175-176.
} 
Ibid., h. 204.

Ibid., h. 192-193.

Report on the Administration of the Mines Department and on the Mining Industries, 1927, h. 9.

Report on the Administration of the Mines Department and on the Mining Industries, 1930, h. 8; Report on the Administration of the Mines Department and on the Mining Industries, 1933, h. 9 .

Report on the Administration of the Mines Department and on the Mining Industries, 1927, 10; Report on the Administration of the Mines Department and on the Mining Industries, 1930, h. 9.

Report on the Administration of the Mines Department and on the Mining Industries, 1935, h. 20.

Annual Report and Accounts of the Electrical Department for the year 1927, h. 6.

Annual Report and Accounts of the Electrical Department for the year 1929, h. 6; Annual Report and Accounts of the Electrical Department for the year 1931, h. 5.

Report on the Administration of the Mines Department and on the Mining Industries, 1939, h. 36.

Ibid. Namun keadaan ini berlaku bukan disebabkan tenaga elektrik tidak berkesan dalam membantu pengusaha menjalankan kerja-kerja melombong sebaliknya ia disebabkan kemerosotan yang berlaku dalam sektor perlombongan itu sendiri. C.O. 717/64/62367, Perak Hydro-Electric Co., h. 136.

Perak Administration Report, 1930, h. 5.

Perak Administration Report, 1932, h. 15; Annual Report on the Social and Economic Progress of the People of Perak, 1933, h. 18.

Report on the Administration of the Mines Department and on the Mining Industries, 1939, h. 28; Report on the Administration of the Mines Department and on the Mining Industries, 1935, h. 20.

J.S. Sidhu, Administration in The Federated Malay States, 1896-1920, Kuala Lumpur: Oxford University Press, 1980, h. 6.

Yip Yat Hoong, The Development of the Tin Mining Industry of Malaya, h. 132.

Ibid., h. 133.

Ibid.

F.T. Ingham \& E.F. Bradford, The Geology and Mineral Resources of the Kinta Valley, Perak, h. 141-142.

Yip Yat Hoong, The Development of the Tin Mining Industry of Malaya, h. 128.

W. Fitzpatrick, "Zaman Gemilang Saya" dalam Noraini Abd Murad (penyunting), Wajahwajah Di Sebalik Cahaya, Kuala Lumpur: Lembaga Letrik Negara Tanah Melayu, 1988, h. 113.

Annual Report and Accounts of the Electrical Department for the year 1933, h. 68.

Annual Report and Accounts of the Electrical Department for the year 1936, h. 77; Annual Report and Accounts of the Electrical Department for the year 1939, h. 62.

C.O. 717/64/62367, Perak Hydro-Electric Co., h. 136.

Annual Report on the Social and Economic Progress of the People of Perak, 1933, h. 18.

Noraini Mohamed Hassan, Penyakit Tropika Di Negeri-negeri Melayu Bersekutu, 1896-1914, Kuala Lumpur: Penerbit Universiti Malaya, 2008, h. 6.

C.O. 717/64/62367, Perak Hydro-Electric Co., h. 136.

W. Fitzpatrick, "Zaman Gemilang Saya" dalam Noraini Abd Murad (penyunting), Wajahwajah Di Sebalik Cahaya, h. 113-114.

Yip Yat Hoong, The Development of the Tin Mining Industry of Malaya, h. 131-133.

Annual Report and Accounts of the Electrical Department for the year 1933, h. 10.

Annual Report and Accounts of the Electrical Department for the year 1937, h. 12.

Annual Report and Accounts of the Electrical Department for the year 1938, h. 18. 